\title{
Study Finds Nation-Building Efforts in Iraq and Afghanistan Hampered By Failures to Address Health Problems
}

\author{
FOR RELEASE
}

Wednesday

April 19, 2006

The United States missed opportunities to help win the support of the public in Iraq and Afghanistan by failing to make health a bigger focus of reconstruction efforts after U.S.-led invasions of the nations, according to a RAND Corporation report issued today.

Efforts to rebuild the public health and health care delivery systems were inadequately funded and the health initiatives that were undertaken focused on projects that had little impact on the daily lives of Iraqis and Afghans, according to the RAND report titled "Securing Health: Lessons from Nation-Building Missions."

In particular, efforts in Iraq faltered by failing to maintain and improve basic sanitation and drinking water services in the nation's most populated areas, which added to anti-Americanism and support for the insurgency, according to the report.

"Nation-building efforts cannot be successful unless adequate attention is paid to the health of the population," said Seth G. Jones, a RAND political scientist and one of the lead authors of the report. "The health status of those living in the country has a direct impact on a nation's reconstruction and development, and history teaches us it can be a key tool in capturing the goodwill of a nation's residents."

Efforts to rebuild health in Iraq and Afghanistan were assessed as part of a report examining the role of public health and health care delivery in seven nation-building missions undertaken since the end of World War II.

In addition, researchers examined the role of public health and health care delivery during the nation-building operations in Germany and Japan after World War II, and the recent cases of Somalia, Haiti and Kosovo.

In the most successful cases, support for health — including basic sanitation, nutrition programs and medical care - has been a key component of successful efforts to establish stable democratic governments after conflicts.

For example, an important step in rebuilding Japan occurred when powdered milk was given to undernourished school children to increase their consumption of protein and calcium. The 
measure improved the health of children and created a surge of goodwill among the Japanese, according to the RAND report.

\section{IRAQ}

RAND researchers say that several measurements show that nation-building efforts in Iraq moved too slowly on many health-related fronts that could have improved the daily lives of the nation's population.

In examining the situation in Iraq, the report says:

- An estimated 40 percent of the water and sanitation network in Baghdad has been damaged during the conflict. Efforts to rebuild the system - aging and in frail condition before fighting began - have moved slowly, hampered by the nation's widespread security problems and looting.

- A year after the major combat phase of the war in Iraq ended, Baghdad's three sewage treatment plants were still inoperable, forcing sewage to be dumped in the Tigris River and putting the nation's population at risk of communicable disease outbreaks. The sewage plants ultimately were repaired, but surveys of Iraqi citizens show that most have been unhappy with the quality of sanitation services - a sign that an opportunity to foster goodwill was lost.

- There were notable health successes, including prevention of malnutrition and communicable disease outbreaks immediately after the U.S.-led invasion, and the reopening of Iraq's hospitals in the months after Saddam Hussein was overthrown.

- Too many of the early efforts in health were focused on issues such as redesigning medical training programs and designing disease-tracking systems — projects that had little immediate and direct impact on the lives of most Iraqis.

- Efforts to address Iraq's health needs have been significantly hurt by the nation's security problems. This has both limited the mobility of workers assigned to health projects and caused policymakers to shift funding from health to security.

\section{AFGHANISTAN}

Looking at the challenges facing U.S. planners in Afghanistan, the RAND report says.

- After 30 years of civil strife, Afghanistan had almost no national health system in place. This meant that the country faced a serious development challenge, and the international community had to build the public health and health care delivery systems virtually from scratch.

- Most of the health problems in Afghanistan are not amenable to quick fixes, requiring long-term investment in nutrition programs, the creation of sanitation systems, and the development of a new generation of health care professionals.

\section{A FRAMEWORK}


The RAND report outlines a framework for policymakers to consider the role that ensuring the health of the population should play in nation-building efforts, providing recommendations for an approach to organize and evaluate such efforts.

Researchers say that the health efforts in Germany and Japan were the most successful ones they studied. Efforts in Kosovo and Iraq were judged as mixed cases, with efforts in Afghanistan, Haiti, and Somalia judged to be the least successful.

Researchers say that well-organized efforts should focus on improving water and sanitation conditions, reducing infectious disease rates, and improving nutrition. Taking these steps will increase the chance that broader nation-building objectives will succeed, the study said.

Coordination of health efforts at the outset of nation-building increasingly is difficult to manage, in part because the number of groups involved with such efforts has expanded sharply since the end of the Cold War, according to the report.

Researchers argue that international donors need to establish institutional arrangements that can help improve coordination. Possible solutions include establishing either a lead country or lead international organization to coordinate planning and funding, especially when the host government is barely functional. However, it is important that responsibility for health be transferred (or given) to local officials as soon as possible to ensure long-term sustainability.

A donation by David and Carol Richards initiated and provided funding for the new study, which was produced by RAND Health's Center for Domestic and International Health Security.

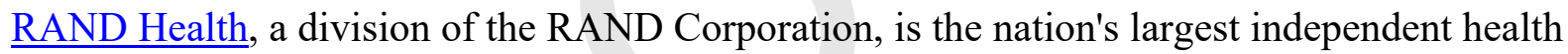
policy research organization, with a broad research portfolio that focuses on health care quality, costs, and delivery, among other topics.

Other authors of the study are Lee. H. Hilborne, C. Ross Anthony, Lois M. Davis, Federico Girosi, Cheryl Benard, Rachel M. Swanger, Anita Datar Garten and Anga Timilsina.

Copies of "Securing Health: Lessons from Nation-Building Missions" (ISBN: 0-8330-3729-3) can be ordered from RAND's Distribution Services (order@rand.org or call toll-free in the U.S. 1-877-584-8642).

- Share on Facebook0

- Share on Twitter

- Share on LinkedIn0

\section{About the RAND Corporation}

The RAND Corporation is a research organization that develops solutions to public policy challenges to help make communities throughout the world safer and more secure, healthier and more prosperous. 


\section{Media Resources}

\section{RAND Office of Media Relations}

(703) 414-4795

(310) 451-6913

media@rand.org

\section{Explore}

All News Releases

- $\quad$ By Date

\section{Related Topics}

- Afghanistan

- Global Security

- Health and Health Care

- Iraq

- Middle East

- Nation Building

- Peacekeeping and Stability Operations

- West Asia

$\underline{\text { Explore All Topics } »}$ 